\title{
Inflation Forecasting by Commodity Using the Autoreggressive Integrated Moving Average (ARIMA) Method
}

\author{
Devi Ambar Wati*, Nurafni Eltivia, Ludfi Djajanto \\ Program Studi Keuangan Jurusan Akuntansi \\ Politeknik Negeri Malang \\ Malang, Indonesia \\ *deviambarw@gmail.com, eltivianurafni@gmail.com, ludfimlg2017@gmail.com
}

\begin{abstract}
The aim of this research is to determine the best Autoregressive Integrated Moving Average (ARIMA) model and its implementation to predict monthly inflation in Indonesia. The data used is the inflation data on the expenditure group of foods, beverages, cigarettes and tobaccos in period January 2010 until December 2019. The method used in this study is the documentation technique. The data analysis technique used is the Autoregressive Integrated Moving Average (ARIMA) which is calculated using the SPSS version 26. The result of this research shows that ARIMA model $(12,0,12)$ is the best model to predict monthly inflation on the expenditure group of foods, beverages, cigarettes and tobaccos in Indonesia for the next period. The results of forecasting 12 months in 2020 with the ARIMA model $(12,0,12)$, in January until April decrease, then for May until August increase while September decrease and in October until December experienced an increase. Therefore, inflation is considered a major problem in the modern economy so that inflationary forecasting can be used in making an economic policy of the coming period which aims to reduce and stabilize price growth.
\end{abstract}

Keywords-forecasting, inflation, Autoreggressive Integrated Moving Average (ARIMA)

\section{INTRODUCTION}

High inflation is indicated by the rising prices of goods or services which will cause people to be unable to buy the goods they need. The development of a country can be measured by looking at its macroeconomic conditions. One of the components of the macro economy is inflation. The stability of inflation is a prerequisite for sustainable economic growth, which in turn will provide benefits for improving people's welfare [1]. Therefore, the importance of controlling inflation is to prevent an increase in inflation that is too high and unstable which will have a negative impact on the socioeconomic conditions of the Indonesian people.

Based on the table below, data from Badan Pusat Statistik 2019, the inflation rate in Indonesia is 2.72. This figure shows a decrease compared to previous years, which was even lower than 2016 of 3.02 which then continued to increase to 3.13 in 2018. see figure 1 below.

\begin{tabular}{|l|c|r|r|r|r|r|r|r|}
\hline \multirow{2}{*}{ Month } & \multicolumn{2}{|c|}{$\mathbf{2 0 1 6}$} & \multicolumn{2}{c|}{$\mathbf{2 0 1 7}$} & \multicolumn{2}{c|}{$\mathbf{2 0 1 8}$} & \multicolumn{2}{c|}{$\mathbf{2 0 1 9}$} \\
\cline { 2 - 9 } & IHK & inflation & \multicolumn{1}{c|}{ IHK } & inflation & IHK & inflation & IHK & inflation \\
\hline January & 123,62 & 0,51 & 127,94 & 0,97 & 132,10 & 0,62 & 135,83 & 0,32 \\
\hline February & 123,51 & $-0,09$ & 128,24 & 0,23 & 132,32 & 0,17 & 135,72 & $-0,08$ \\
\hline March & 123,75 & 0,19 & 128,22 & $-0,02$ & 132,58 & 0,20 & 135,87 & 0,11 \\
\hline April & 123,19 & $-0,45$ & 128,33 & 0,09 & 132,71 & 0,10 & 136,47 & 0,44 \\
\hline May & 123,48 & 0,24 & 128,83 & 0,39 & 132,99 & 0,21 & 137,40 & 0,68 \\
\hline June & 124,29 & 0,66 & 129,72 & 0,69 & 133,77 & 0,59 & 138,16 & 0,55 \\
\hline July & 125,15 & 0,69 & 130,00 & 0,22 & 134,14 & 0,28 & 138,59 & 0,31 \\
\hline August & 125,13 & $-0,02$ & 129,91 & $-0,07$ & 134,07 & $-0,05$ & 138,75 & 0,12 \\
\hline September & 125,41 & 0,22 & 130,08 & 0,13 & 133,83 & $-0,18$ & 138,37 & $-0,27$ \\
\hline October & 125,59 & 0,14 & 130,09 & 0,01 & 134,20 & 0,28 & 138,40 & 0,02 \\
\hline November & 126,18 & 0,47 & 130,35 & 0,20 & 134,56 & 0,27 & 138,60 & 0,14 \\
\hline December & 126,71 & 0,42 & 131,28 & 0,71 & 135,39 & 0,62 & 139,07 & 0,34 \\
\hline inflation rate & & $\mathbf{3 , 0 2}$ & & $\mathbf{3 , 6 1}$ & & $\mathbf{3 , 1 3}$ & & $\mathbf{2 , 7 2}$ \\
\hline
\end{tabular}

Source: Badan Pusat Statistik. 2019.

Fig. 1. Indonesian monthly consumer price index and inflation period for the 2016-2019.

With the decline of the inflation rate in Indonesia, it can be said that the inflation rate in Indonesia can still be controlled. This is because from its historical perspective, Indonesia even experienced an inflation rate of 8.5 in 2014. The Institute for Development of Economic (INDEF) assesses that Indonesia's current inflation is relatively low, but regionally it is still the highest in Asean [2].

The high rate of inflation in Indonesia, as illustrated above, can be influenced by certain commodities. Commodities that play a major role or influence in changes of the inflation rate in Indonesia, one of them is processed food, beverages, cigarettes and tobacco [3]. This condition is due to the fact that the majority of Indonesians are very consumptive and want practical and instant things. If the inflation rate is not well managed in this expenditure group, it will have an impact on inflation in Indonesia generally. 
Inflation in Indonesia as measured by the Consumer Price Index (CPI). Of the seven expenditure groups, the processed food, beverages, cigarettes and tobacco group are currently the most influential expenditure groups. This is because the majority of Indonesians are very consumptive people and want practical and instant things [4]

In addition, during the last 5 years, inflation in the expenditure group for processed food, beverages, cigarettes, and tobacco together with the clothing expenditure group, the inflation value has always been consistently above figure 3 . Expenditure on processed food, beverages, cigarettes and tobacco is always higher than the expenditure on clothing. This data proves that the processed food, beverages, cigarettes and tobacco groups are the most influential expenditure groups, at least during the last 5 years.

Research related to inflation forecasting has received a lot of positive attention from macroeconomic researchers. Most central banks use the future inflation rate as a form of consideration for taking monetary policy. One of inflation management is forecasting inflation. Forecasting inflation is a bridge to determine the value of inflation for the coming period. Inflation forecasting is not only based on historical data on the inflation rate, but also must pay attention to or take into account the factors that influence the fluctuation of the inflation rate and certain events that cause intervention in the increase of the inflation rate. Obtaining an accurate forecasting inflation value will be important for many parties, including determining monetary and fiscal policy, making investment decisions and knowing how much purchasing power of the society.

Forecasting is very useful to provide an overview of what will happen in the future so that it becomes one of the considerations in decision making. If forecasting inflation is carried out using a good method, it will be able to help the government in making economic policies and other policies to produce good policies. For the government, inflation forecasting is a bridge to determine the value of future inflation. This research is a development of inflation forecasting in Indonesia that provides input for Bank Indonesia in considering policy making.

The executed forecasting inflation, usually using data time series. Time series is an analysis that explains and measures various changes or developments in data during a period [5]. In addition, time series is a statistical method that models an observational data taken in a time series, either hourly, daily, weekly, monthly, semester, quarterly or annually. Time series is very appropriate to be used to predict patterned conditions and is quite consistent over a long period of time, so that the pattern will still continue. The purpose of the periodic series method is to find patterns in data series and extrapolate these series patterns to the future [6]

There are many methods that can be used in modeling data time series, but it must be adjusted to the characteristics and variables of the data in order to obtain the best model. To obtain the required information regarding the inflation rate, the method used is the Autoregressive Integrated Moving Average (ARIMA). The ARIMA method is a model formation for analyzing periodic series data, this method is often used as a forecasting method because it provides a thorough study and it is suitable for inflation rate data. This model assumes that the model residuals are white noise and normally distributed. Model estimation is done using the Maximum Likelihood Estimator (MLE) method. MLE is a method of estimating the parameters of a probability distribution based on the function likelihood.

This study aims to determine the best model Autoregressive Integrated Moving Average (ARIMA) that can be used to predict monthly inflation for the food, beverage, cigarette and tobacco expenditure groups in Indonesia on the coming period; and Knowing the application of the forecasting method using the model Autoregressive Integrated Moving Average (ARIMA) to predict the monthly inflation of the food, beverage, cigarette and tobacco expenditure groups in Indonesia.

\section{THEORY}

\section{A. Forecasting}

According to Heizer and Render [7], forecasting is an art and science for predicting future events. This can be done by involving taking historical data and projecting it into the future with some form of mathematical model. Forecasting is usually done to reduce uncertainty about something that will happen in the future.

\section{B. Inflation}

Inflation can be interpreted as a symptom of a general and continuous increase in the price of goods [8]. Based on this definition, there are three conditions to say that inflation has occurred. First, there is an increase in prices. Second, the increase occurred in the prices of goods in general. Third, the increase lasted quite a long time. Thus, a price increase that occurs for only one type of goods, or an increase that occurs only temporarily cannot be called inflation.

\section{Time Series}

According to Boediono [9], periodical data or time series is data that is usually used to describe a development or trend of circumstances or events or activities. Usually the distance or interval from time to time is same. Examples of periodic data are as follows: (1) the economic growth of a country per year; (2) the amount of oil production per month; (3) stock price index per day.

Time series is a quantitative method used to determine data patterns in the past that have been collected regularly according to the time sequence of events (weekly, monthly, annually, etc.) and are usually tabulated in graphical form. The purpose of time series research is to model, predict and project data based on the past data to the future by utilizing mathematical equations and statistics.

\section{Autoreggressive Integrated Moving Average (ARIMA)}

The Autoregressive Integrated Moving Average (ARIMA) method is a forecasting method that does not use theory or influence between variables such as the regression model, thus the ARIMA method does not require an explanation of which variables are dependent and independent. This method does not 
require breaking the pattern into components trend, seasonal, cyclical or irregular as in data time series generally. This method purely makes predictions based only on existing historical data. Apart from being known as ARIMA, this method is popularly known as the method Box-Jenkins, because it was developed by two American statisticians, namely GEP Box and GM Jenkins in 1970 [10].

According to Mulyono [11] the Box-Jenkis method can only be applied, explained, or represented a stationary series or has been made stationary through the process differencing. Because the stationary series does not have an element trend, what this method wants to explain is the remaining element, namely error. The model groups time series linear included in this method include: moving average, autoregressive, autoregressive-moving average, and autoregressive integrated moving average.

According to Arsyad [12], the Forecasting method is BoxJenkins different from almost all other forecasting methods. This method uses an iterative approach in identifying the most appropriate model of all possible models. The model that has been selected is tested again with historical data to see whether the model describes the state of the data accurately or not. There are four stages in forecasting using the ARIMA (method Box-Jenkins), namely the stage of model identification, model parameter estimation, model verification and forecasting.

\section{RESEARCH METHODS}

The object of this study is inflation in the group of expenditures for processed food, beverages, cigarettes and tobacco in Indonesia during the period January 2010 to December 2019. The data source used in this study is secondary data, namely monthly inflation data in the processed food expenditure group, beverages, cigarettes and tobacco in Indonesia during the period January 2010 to December 2019. The data collection method used in this study is documentation techniques, data required for monthly inflation in the expenditure group for processed food, beverages, cigarettes and tobacco in Indonesia during the January 2010 period until December 2019 which is obtained through the website bps.go.id. This type of research is a quantitative descriptive study because the data processed for this study is in the form of numbers.

After the required data has been collected, the next step is to analyze the data. The analysis was conducted to forecast monthly inflation data for the food, beverage, cigarette and tobacco expenditure groups in Indonesia using the Autoreggressive Integrated Moving Average (ARIMA) method. To facilitate the data analysis process, the researchers used the IBM SPSS Statistics 26 software. The analysis design carried out is:

\section{A. Model Identification}

Process of identifying the model begins with plotting the existing data graphically. Based on the data plot created, then stationary testing is carried out. If it is known that the data is not stationary in the mean then it needs to be stationary by means of differences (differencing), where as if the data is not stationary in variants then carried out transformation of data, if the data is stationary then the ACF and PACF values are sought and formulate a general model.

\section{B. Search for Model Parameters and Set A Provisional Model}

Process Integrated Moving Average Autoreggressive symbolized by ARIMA ( $p, d, q)$, with $p$ indicate the order/degree autoregressive (AR); $d$ is the level of the process differencing; and $\mathrm{q}$ denotes the order/degree of the moving average (MA). A series may be non-stationary, homogeneous, not composed of the two processes, namely the process autoregressive or the moving average. If it only contains an autoregressive process, then the series is said to follow a process integrated autoregressive and is denoted ARIMA ( $\mathrm{p}, \mathrm{d}$, $0)$. Meanwhile, those containing only the process moving average, the series is said to follow the Integrated moving average process and is written $\operatorname{ARIMA}(0, d, q)$.

After the time series data has been stationary, the next step is to determine the ARIMA (p, d, q) model that is suitable (tentative), which means determining how many $\mathrm{p}, \mathrm{d}$, and $\mathrm{q}$ are. If without the process differencing $d$ is given a value of 0 , if it becomes stationary after the first order differencing $d$ is 1 and so on. In choosing how many $\mathrm{p}$ and $\mathrm{q}$ can be helped by observing the pattern of the function autocorrelation (ACF) and partial autocorrelation (PACF) of series the analyzed. In practice, the patterns autocorrelation and partial autocorrelation often do not resemble one of the patterns in the table due to variations sampling. The error of selecting $\mathrm{p}$ and $\mathrm{q}$ is not a problem, and will be understood after the stage diagnostic checking.

\section{Diagnostic Checking}

Test whether these parameters are significant and it is feasible to be used as a model (by validating the model using real data). If it is not feasible, it is necessary to test the suitability of the model by looking for other alternative models.

\section{Selection of the Best Model}

At this stage, the model obtained in the previous stage has more than 1 model, in determining the best model can be seen from the values of $R$-Squared, MAPE and RMSE. The values $R$-Squared and larger the smaller MAPE and RMSE indicate that this model is the best model.

\section{E. Forecasting}

After the correct model has been found, forecasting for one period or several periods to come can be determined.

\section{RESULTS}

Data processed in this study were obtained from the Central Statistics Agency (BPS). The data used are monthly data for the period January 2010 to December 2019. It can be seen in figure 2, as follows: 


\begin{tabular}{|l|c|c|c|c|c|c|c|c|c|c|}
\hline \multirow{2}{*}{ Month } & \multicolumn{10}{|c|}{ Years } \\
\cline { 2 - 12 } & $\mathbf{2 0 1 0}$ & $\mathbf{2 0 1 1}$ & $\mathbf{2 0 1 2}$ & $\mathbf{2 0 1 3}$ & $\mathbf{2 0 1 4}$ & $\mathbf{2 0 1 5}$ & $\mathbf{2 0 1 6}$ & $\mathbf{2 0 1 7}$ & $\mathbf{2 0 1 8}$ & $\mathbf{2 0 1 9}$ \\
\hline January & 1,93 & 0,49 & 0,65 & 0,46 & 0,72 & 0,65 & 0,51 & 0,47 & 0,43 & 0,27 \\
\hline February & 0,40 & 0,47 & 0,34 & 0,47 & 0,43 & 0,45 & 0,63 & 0,39 & 0,43 & 0,31 \\
\hline March & 0,28 & 0,32 & 0,46 & 0,40 & 0,43 & 0,61 & 0,36 & 0,31 & 0,26 & 0,21 \\
\hline April & 0,24 & 0,20 & 0,62 & 0,30 & 0,45 & 0,50 & 0,35 & 0,12 & 0,24 & 0,19 \\
\hline Mav & 0,34 & 0,22 & 0,40 & 0,35 & 0,35 & 0,50 & 0,58 & 0,38 & 0,31 & 0,56 \\
\hline June & 0,41 & 0,41 & 0,48 & 0,67 & 0,32 & 0,55 & 0,58 & 0,39 & 0,40 & 0,59 \\
\hline July & 0,65 & 0,42 & 0,89 & 1,55 & 1,00 & 0,51 & 0,54 & 0,57 & 0,45 & 0,24 \\
\hline August & 0,67 & 0,46 & 0,67 & 0,68 & 0,52 & 0,71 & 0,41 & 0,26 & 0,35 & 0,26 \\
\hline September & 0,52 & 0,48 & 0,57 & 0,78 & 0,51 & 0,39 & 0,34 & 0,34 & 0,29 & 0,28 \\
\hline October & 0,48 & 0,26 & 0,38 & 0,55 & 0,43 & 0,40 & 0,24 & 0,28 & 0,27 & 0,45 \\
\hline November & 0,46 & 0,20 & 0,20 & 0,27 & 0,71 & 0,47 & 0,25 & 0,22 & 0,20 & 0,25 \\
\hline December & 0,36 & 0,50 & 0,29 & 0,73 & 1,96 & 0,50 & 0,45 & 0,30 & 0,22 & 0,29 \\
\hline mean & $\mathbf{0 , 5 6}$ & $\mathbf{0 , 3 7}$ & $\mathbf{0 , 5 0}$ & $\mathbf{0 , 6 0}$ & $\mathbf{0 , 6 5}$ & $\mathbf{0 , 5 2}$ & $\mathbf{0 , 4 4}$ & $\mathbf{0 , 3 4}$ & $\mathbf{0 , 3 2}$ & $\mathbf{0 , 3 3}$ \\
\hline
\end{tabular}

Source: Badan Pusat Statistik, 2019.

Fig. 2. Monthly inflation data for the group on expenditures for food, beverages, cigarettes and tobacco in 2010-2019 (in Percent).

Based on figure 2 above, the next step in data analysis time series is to plot the data graphically. The monthly inflation data for the last 10 years can be graphed as figure 3 follows:

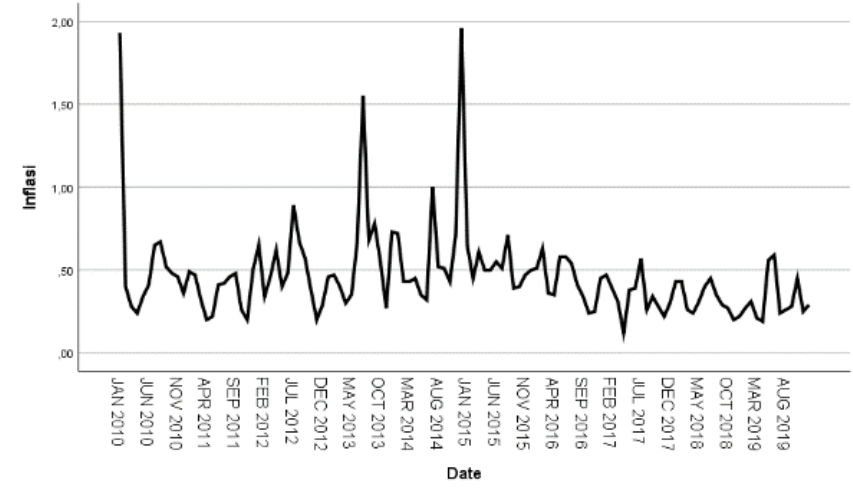

Source: Processed data, 2020

Fig. 3. Plot of 2010-2019 monthly inflation data.

Figure 3 above shows that the inflation rate from January 2010 to December 2019 only experienced an increase or decrease in certain periods and tended to be stable at the middle value. In other words, the data fluctuations are around a constant average value. Therefore, the data has been stationary to the mean, because the observed data did not experience too large fluctuations from time to time and the data was around the average value, 0.46 .

Based on the information above, the time series data will be more suitable if processed using the method Autoreggressive Integrated Moving Average (ARIMA). To determine the error rate of forecasting with actual data, it is necessary to calculate the error rate or error. In determining the level of error, this study uses Root Mean Square Error (RMSE), Mean Absolute Percentage Error (MAPE), Mean Absolute Error (MAE). This study uses the application IBM SPSS Statistics 26 software. Knowing the results diagnostic checking of the residual measurements shows that all ARIMA models used have been specified correctly because the residues of all ARIMA models are random or inter-error is not related. Meanwhile, based on diagnostic checking using the Modified Box-Pierce (LjungBox) Q Statistic, of the 11 models tested, only 5 models were left that could be specified correctly, namely ARIMA $(1,0,0)$, ARIMA $(5,0,0)$, ARIMA $(5,0,1)$, ARIMA $(12,0,12)$ and ARIMA $(0,0,1)$. Thus, the five models will be used to forecast or predict monthly inflation for the group of processed food, beverage, cigarette and tobacco expenditures in Indonesia in the next 1-year period. The results of forecasting that have been carried out are as follows:

The results of forecasting that have been carried out using the ARIMA model $(0,0,1)$ show that the fit value in forecasting data with the ARIMA model $(0,0,1)$ is quite far from the actual data and it can be seen that the curve is less aligned with the actual data curve. In addition, the results of the monthly inflation prediction for the next 12 -month period is very flat and only showed a rising trend in the second month and then static until month 12 .

The results of forecasting have been done by using ARIMA $(1,0,0)$ indicates that the value fit in Forecasting data using ARIMA model $(1,0,0)$ is quite far from the actual data and it can be seen that the curve does not coincide with the actual data curve. In addition, the results of monthly inflation predictions for the next 12 months only show an increasing trend in the first 3 months and then flat until the 12th month.

Forecasting results that have been carried out using the ARIMA model $(5.0,0)$ show that the fit value in the forecasting data with the ARIMA model $(5,0,0)$ it is quite far from the actual data and it can be seen that the curve does not coincide with the actual data curve. In addition, the results of the monthly inflation prediction for the next 12 months are relatively flat and do not show any significant changes in trend.

The results of forecasting that have been done using the ARIMA model $(5,0,1)$ show that the fit value in the forecasting data with the ARIMA model $(5,0,1)$ is quite far from the actual data and it can be seen that the curve does not coincide with the actual data curve. In addition, the results of the monthly inflation prediction for the next 12 months are relatively flat and do not show any significant changes in trend.

The results of forecasting that have been done using the ARIMA model $(12,0,12)$ show that the fit value in forecasting data with the ARIMA model $(12,0,12)$ is almost close to the actual data and it can be seen that the curve is quite coincided with the actual data curve. In addition, the results of monthly inflation predictions for the next 12 months show a significantly changing trend.

The ARIMA forecasting model $(\mathrm{p}, \mathrm{d}, \mathrm{q}$ ) will provide different forecasting results, so one of the best models must be selected, namely a model that shows a good level of accuracy. There are several criteria for selecting the best model, using actual data with the value of forecasting (forecasting). In this research, several ARIMA prediction models have been carried out. The results of the prediction model show the deviation of the predicted results from the actual data values, as already defined, namely RMSE, MAPE and MAE. 
TABLE I. ARIMA MODEL KINDNESS SIZE

\begin{tabular}{|c|c|c|c|}
\hline \multirow{2}{*}{ Model } & \multicolumn{3}{|c|}{ Model Fit Statistic } \\
\cline { 2 - 4 } & RMSE & MAPE & MAE \\
\hline ARIMA (1,0,0) & 0,263 & 36,008 & 0,151 \\
\hline ARIMA (5,0,0) & 0,263 & 35,183 & 0,151 \\
\hline ARIMA (5,0,1) & 0,263 & 34,475 & 0,149 \\
\hline ARIMA (12,0,12) & 0,260 & 32,601 & 0,146 \\
\hline ARIMA (0,0,1) & 0,262 & 36,097 & 0,152 \\
\hline
\end{tabular}

Based on the table above, it can be seen that of the five ARIMA models, there is one ARIMA model value which gives the smallest deviation value is the ARIMA model $(12,0,12)$, namely the RMSE of 0.260 , the MAPE of 32.601 , and the MAE of 0.146 . Thus, the ARIMA model $(12,0,12)$ is the best model for predicting monthly inflation in the processed food, beverage, cigarette and tobacco group in Indonesia in the coming period.

This research was conducted to create a monthly inflation forecasting model for the processed food, cigarette and tobacco group in Indonesia and is used to predict the inflation rate in 2020. The data used to be analyzed is monthly inflation data for the last 10 years from January 2010 to December 2019. This inflation forecasting is important to do because inflation is one of the important macro indicators in providing information about the economic turmoil of a nation and is an important factor in making monetary decisions.

The results of this study indicate that the monthly inflation data for the processed food, cigarette and tobacco group in Indonesia from January 2010 to December 2019 is data time series a stationary, so that in the subsequent analysis process, is not required differencing. Furthermore, from the results of parameter estimation, 11 possible models are obtained, namely ARIMA $(1,0,0)$, ARIMA $(1,0,1)$, ARIMA $(1,0,12)$, ARIMA $(5,0,0)$., ARIMA $(5,0,1)$, ARIMA $(5,0,12)$, ARIMA $(12,0,0)$, ARIMA $(12,0,1)$, ARIMA $(12,0,12)$, ARIMA $(0,0,1)$, ARIMA $(0,0,12)$. Furthermore, based on the results of diagnostic checking, of the 11 possible models, the remaining 5 models are correctly specified, namely ARIMA $(1,0,0)$, ARIMA $(5,0,0)$, ARIMA $(5,0,1)$., ARIMA $(12,0,12)$ and ARIMA $(0,0,1)$. These five models were chosen to be used for forecasting.

Furthermore, based on the results of forecasting, it is known that of the five models tested, there is only one model, namely ARIMA $(12,0,12)$ which results show the fit value in the forecasting data which is almost close to the actual data. In addition, the forecast data using the ARIMA model $(12,0,12)$ also shows significant fluctuations or trends. While the other four models, namely ARIMA $(1,0,0)$, ARIMA $(5,0,0)$, ARIMA $(5,0,1)$, and ARIMA $(0,0,1)$, the results show the fit value of the value. Fit The value in the forecasting data is quite far from the actual data, and the data tends to be flat with the forecast result value which tends to be static from month 1 to month 12 .

These results are sufficient to describe the model that has the best results for forecasting. This is then confirmed by the results of test the fit statistical model to select the best model from the five tested models. From the test results, it is found that the ARIMA model $(12,0,12)$ has an RMSE value of 0.260 , a MAPE of 32.601, and an MAE of 0.146 which is smaller than the other four models. Thus, it can be explained that the ARIMA model $(12,0,12)$ is the best model for predicting monthly inflation in the processed food, beverage, cigarette and tobacco group in Indonesia in the following 12 months. The values obtained from the forecasting results of monthly inflation predictions in the processed food, beverage, cigarette and tobacco group in Indonesia using the ARIMA model $(12,0,12)$ in the period January to December 2020 are as follows:

TABLE II. RESUlTS OF THE ARIMA MODEL INFLATION FORECASTING $(12,0,12)$ IN 2020

\begin{tabular}{|l|l|}
\hline \multicolumn{1}{|c|}{ Month/Years } & Inflation Result Forecast \\
\hline January 2020 & 0,55 \\
\hline February 2020 & 0,48 \\
\hline March 2020 & 0,30 \\
\hline April 2020 & 0,27 \\
\hline May 2020 & 0,39 \\
\hline June 2020 & 0,47 \\
\hline July 2020 & 0,50 \\
\hline August 2020 & 0,46 \\
\hline September 2020 & 0,34 \\
\hline October 2020 & 0,38 \\
\hline November 2020 & 0,40 \\
\hline December 2020 & 0,46 \\
\hline
\end{tabular}

The forecast results (Table 2) for the monthly inflation rate for the food, beverage, cigarette and tobacco expenditure group in 2020 have an average value of 0.42 , indicating an increase compared to the previous three years, due to the average inflation in 2017, 2018, and 2019 respectively, the magnitude is $0.34 ; 0.32$ and 0.33 . However, the average inflation forecast in 2020 is not higher than the average inflation in 2012-2016. The results of this forecast also show that during the first four months of 2020, inflation showed a high value in January and then continued to decline until April. This is in line with the actual inflation data for the expenditure group for processed food, beverages, cigarettes and tobacco obtained from BPS during the first 4 months of 2020 which shows the same pattern, namely high in January and continuing to decline until April 2020. From BPS data shows that inflation in the expenditure group for processed food, beverages, cigarettes and tobacco in January 2020 was 1.62 , fell to 0.95 in February, fell sharply to 0.10 in March, and fell again to 0.09 in April.

The results of this study support the results of previous studies which show that the ARIMA model can be used to forecast inflation rates. Among them are Desvina and Desmita's [13] research, whose results show that the ARIMA model is a suitable model for predicting the consumer price index/inflation in Pekanbaru City. Like the results of this study, the results of forecasting in Desvina and Desmita's [13] study also show that the forecasted price index data has increased and decreased at certain times. Likewise, with Hartati's [14] research, whose results show that one of the good forecasting methods used to predict the inflation rate is using ARIMA. 


\section{CONCLUSION AND SUGGESTION}

\section{A. Conclusion}

Based on the results of the analysis and discussion that has been done about forecasting inflation using the ARIMA ( $p, d$, q) model, it can be concluded that:

- This study found that the inflation data for the food, beverage, cigarette and tobacco expenditure group for the period January 2010 to December 2019 is time series a stationary. Therefore, ARIMA analysis can be directly carried out, because the data used has to be stationary so it does not need to be done using the data transformation process of differencing.

- Of the 11 possible models for forecasting, based on results diagnostic checking obtained 5 models that are correctly specified, namely ARIMA $(0,0,1)$, ARIMA $(1,0,0)$, ARIMA $(5,0,0)$, ARIMA $(5,0,1)$, and ARIMA $(12,0,12)$, which is then used to make forecasts.

- From the results of testing the best model for forecasting, it is found that the ARIMA model $(12,0,12)$ has an RMSE value of 0.260 , a MAPE of 32.601, and an MAE of 0.146 which is smaller than the other four models. Thus, the ARIMA model $(12,0,12)$ is the best model for predicting monthly inflation in the processed food, beverage, cigarette and tobacco groups in Indonesia in the next period.

- The results of forecasting monthly inflation in the processed food, beverage, cigarette and tobacco group in Indonesia for 12 months in 2020 using the ARIMA model $(12,0,12)$ are 0.55 in January; 0.48 in February; 0.30 in March; 0.27 in April; 0.39 in May; 0.47 in June; 0.50 in July; 0.46 in August; 0.34 in September; 0.38 in October; 0.40 in November; and 0.46 in December.

\section{B. Suggestions}

Based on the above conclusions, several suggestions can be made as follows:

- The model that has been obtained in the discussion of this thesis, the researcher hopes that it can be taken into consideration for interested parties in controlling inflation, especially the government and the central bank.
- The result of forecasting is not a certain value that will occur in the coming period. Given the many factors in the field that sometimes have a significant influence on the final result. Meanwhile, time series data modeling can be done using ARIMA, SARIMA and ARIMAX. Therefore, other researchers can learn more about inflation-related time series modeling using SARIMA and ARIMAX which have not been discussed in this thesis.

\section{REFERENCES}

[1] R.F. Suhartono, D.A. Lusia, B.W. Otok, and H.K Sutikno, "Ensemble Method based on ANFIS-ARIMA for Rainfall Prediction," 2013.

[2] tobbusiness.id, 2018

[3] BPS, 2019.

[4] A.L. Berlian, Y. Wilandari, and H. Yasin, "Peramalan Inflasi Menurut Kelompok Pengeluaran Makanan Jadi, Minuman, Rokok dan Tembakau Menggunakan Model Variasi Kalender (Studi Kasus Inflasi Kota Semarang)," Jurnal Gaussian, vol. 3, no. 4, pp. 547 - 556, 2014.

[5] S. Munir, H. Hasan, and M. Muhammad, "The effect of trade openness on inflation: Panel data estimates from selected Asian economies (19762010)," Southeast Asian Journal of Economics, pp. 23-42, 2015.

[6] S. Makridakis, S.C. Wheelwright and V.E. McGee, Metode dan Aplikasi Peramalan. Jakarta: Binarupa Aksara, 2005.

[7] J. Heizer and B. Render, Manajemen Operasi: Manajemen Keberlangsungan dan Rantai Pasokan (Edisi 11). Jakarta: Salemba Empat, 2014.

[8] P. Rahardja and M. Manurung, Teori Ekonomi Makro: Suatu Pengantar (Edisi 5), Jakarta: Lembaga Penerbit Fakultas Ekonomi Universitas Indonesia, 2018.

[9] Boediono, Ekonomi Makro: Seri Sinopsis Pengantar Ilmu Ekonomi No. 2. Yogyakarta: BPFE, 2008

[10] S. Santoso, Buisness Forecaseting Metode Peramalan Bisnis Masa. Kini dengan Minitab dan SPSS. Jakarta: Elex Media Komputindo, 2009.

[11] S. Mulyono, Peramalan Bisnis Dan Ekonometrika. Yogyakarta: BPFE 2000.

[12] L. Arsyad, Peramalan Bisnis (Edisi Pertama). Yogyakarta: BPFE, 2001

[13] A.P. Desvina and E. Desmita, "Penerapan Metode Box-Jenkins Dalam Meramalkan Indeks Harga Konsumen di Kota Pekanbaru," Jurnal Sains Matematika dan Statistika, vol. I, no. 1, pp. 39-47, 2015.

[14] Hartati, "Penggunaan Metode Arima Dalam Meramal Pergerakan Inflasi," Jurnal Matematika, Saint, dan Teknologi, vol. 18, no. 1, pp. 1$10,2017$. 